\title{
Use of ICTs as a Source of Information for Improving Agricultural Productivity in South-West, Nigeria
}

\author{
Toluwase S. O. W., Apata O. M. \\ Department of Agricultural Economics and Extension Services, Faculty of Agricultural Sciences, Ekiti State University, Ado Ekiti, Nigeria
}

\section{Email address:}

Sunday.toluwase@eksu.edu.ng (Toluwase S. O. W.)

\section{To cite this article:}

Toluwase S. O. W., Apata O. M. Use of ICTs as a Source of Information for Improving Agricultural Productivity in South-West, Nigeria. International Journal of Agricultural Economics. Vol. 2, No. 3, 2017, pp. 50-54. doi: 10.11648/j.ijae.20170203.11

Received: March 8, 2017; Accepted: March 27, 2017; Published: April 13, 2017

\begin{abstract}
The study investigates respondent's access to use of ICTs as a source of information for improving agricultural productivity. A well-structured questionnaire was used for data collection from the respondents. The specific objectives of the study that addressed Socio- economic characteristics, awareness of various ICTs, knowledge on ICT use and constraints facing ICT usage. Data collected was analyzed using descriptive statistics such as frequency, percentage, mean. Inferential statistics such as Chi-Square was used to establish relationship. The results obtained revealed that family members constitute the major source of information to the famers in the study areas. This is followed by radio, mobile phone and internet while extension agents rarely provide information to the famers. Findings also revealed a high rate of competence in the use of mobile phones, radio, and television sets while respondents indicated low competence level in the use of video-conferencing and fax, the attitude of farmers has a significant level of effect on the productivity of farmers. Their attitude had a $10 \%$ level of significance on the productivity among others. Policy makers should try to make agricultural information readily available through mobile devices, since they were most commonly used and since most farmers did not have contact with extension agents; hence more extension agents should be engaged in order to reach the farmers adequately.
\end{abstract}

Keywords: Information and Communication Technologies, Source, Information, Agricultural, Productivity

\section{Introduction}

Information and communication technology (ICT) is an incorporated system which entails use of computers and mobile telecommunication gadgets and television. Global attention is being directed towards agriculture due to the emerging challenges of food security in recent years, resulting partly from age long negligence of dissemination of appropriate technology. Small scale farmers who dominate the landscape of developing countries need to improve farming by acquiring adequate knowledge and information [1]. Agriculture, contributes immensely to the Nigerian economy in various ways, namely, in the provision of food for the ever increasing populace, supply of adequate raw materials to a growing industrial sector, a major source of employment, generation of foreign exchange earnings and provision of a market for the products of the industrial sector [2].

The role of agricultural extension services has traditionally been to provide the important link between agricultural researchers and farmers, especially for technology transfer in support of agricultural development. However, strong criticism of public agricultural extension services has circulated in recent years [3], this criticism is due to its topdown approach, which has been supply driven, technically weak, catering for only large scale farmers and providing insufficient coverage of the small scale farmers. This implies that proven agricultural technologies needed to ensure higher productivity and subsequently food security and effectively reach the small scale farmers scattered in rural areas. Agricultural extension which depends largely on exchange of information between and among farmers and a broad range of other actors in the agricultural sector is an area in which ICTs can have significant impact, hence researchers can relate directly with farmers through ICTs.

[4] opined that the use of ICT is becoming popular as more and more farmers are no longer interested in the traditional ways of keeping farm data and records. This is because they are relatively simple to use and satisfy the recording and information requirements of many farmers.

A major setback affecting adoption and diffusion of 
technology in developing countries is the set of barriers obstructing widespread acceptance and usage in developing countries. According to [4], commercial farmers in South Africa are now using ICTs in the management of farm enterprises. Technological infrastructure encompasses technological tools, methods and access models that are used to facilitate the efficient management and transfer of information. Lack of adequate technological infrastructure has remained a major obstacle to use of ICTs in most developing countries. [5] said the infrastructural investment required for the uptake of ICTs far exceeds the resources of most developing countries and is very expensive or not commercially viable. [6], noted that poor people do not have access to information, knowledge and communication. This is because ICTs is largely relied on telecommunication infrastructure. Therefore, without these facilities, access to ICT is impossible. [10] found that most developing countries have the lowest access to ICTs resources and within these countries; there is a notable digital divide between the rural and urban areas, the rich and the poor population. The inaccessibility to ICTs resources makes it difficult for the rural traditionally unheard people to have a voice in the happenings in the world. Though, the use of computers in Africa is increasing, internet connectivity is still poor and expensive, affecting the access to information and the ability to make informed decisions by farmers. In rural areas of developing countries, the use of ICTs to connect sources of agricultural innovation to farmers is limited by lack of internet connectivity. Radios, television, slides, and field demonstrations are still been majorly used to disseminate information in the rural areas. According to [7], even when infrastructure is available, affordable access is a concern in most developing countries. ICTs equipment are expensive and unaffordable to the majority of the inhabitants of developing countries, thereby cutting down the number of people who are able to use the technology [8]. The initial cost of ICTs and the costs of maintaining them are high, thereby reducing the number of people able to afford them. One of the major obstacles affecting ICTs diffusion is the price charged end-users by ICTs service providers. As a result, a lot of potential users are barred from using these services because of the high cost. Developing countries have the highest number of illiterates, hence, ICTs face a huge challenge of being effectively used by these communities, because, most of these devices come with rules and guidelines. There is a lack of communal awareness about the potential benefits and capabilities of ICTs. [9] noted a critical need for ICTs training for end users to cater for the ever changing information and internet characteristics. The general objective of the study is to assess respondent's use of ICTs as a source of information for improving agricultural productivity while its specific objectives were to; describe the socio-economic characteristics of farmers, ascertain most commonly used method of ICTs among the farmers, identify the constraints on ICTs use and describe the level of awareness of ICTs by the farmers.

\section{Methodology}

\subsection{Study Area}

This study area was carried out in south-western Nigeria which comprises of six states which are Ekiti, Ogun, Ondo, Osun, Oyo and Lagos. The south west region of Nigeria is culturally homogenous and populated mainly by the Yoruba ethnic group and is hence unified by a general language, Yoruba.

\subsection{Method of Data Collection}

The instrument that was used for the study was a wellstructured questionnaire which addressed: Socio-economic characteristics, awareness of various ICTs, knowledge on ICT use, and the constraints on ICT use, oral interview schedule and close observations were also used for data collection. Visitation was made to each of the selected Local Government Areas for administration of questionnaire as well as to interview the respondents. Closed questions were used.

\subsection{Method of Data Analysis}

The obtained data were analyzed using descriptive statistics such as frequency, percentage, mean. Inferential statistics such as Chi-Square was used to analyze the data.

\section{Results and Discussion}

Table 1 reveals the socio-economic characteristics of the respondents. From the table it shows that $73.3 \%$ and $26.7 \%$ were male and female farmers respectively, implying that farming activities is being handled most by the male in the study area. Also from the table, the age distribution of the respondents which ranges from 40-60 years has the highest proportion $(79.2 \%)$. This indicate that ICT users in the study area are mature people and thus will handle the different ICT medium properly if they are given the necessary enlightenment.

The marital status of the respondents in table 1 revealed that majority $(70.8 \%)$ were married, $10.8 \%$ were single and $10.1 \%$ were divorced and $8.3 \%$ were widowed. This indicates that most of the ICT users in the study area are married and thus responsible, they will not misplace the main priority of the ICT for other reasons.

The findings shows that majority of the respondents attended up to secondary school $(36.7 \%)$, hence they are able to read and write which will make ICT usage easy to use by them.

Table 1 also revealed that the respondents are into different types of farming activities and thus requires different level of information to help them increase their level of productivity necessitating the important of ICT usage in the study area.

Table 1 also revealed the annual income of the respondents in the study area. Majority of the respondents have annual income of 20,000-200,000(50.8\%), this indicates that most of the ICT users in the study area have considerable income 
and thus may help in purchasing the different ICT media needed to help them source for information needed to improve their productivity.

Table 1. Socio-economic Characteristics of Respondents.

\begin{tabular}{|c|c|c|}
\hline Variables & Frequency & Percentage (\%) \\
\hline \multicolumn{3}{|l|}{ Age group (years) } \\
\hline $20-40$ & 18 & 15 \\
\hline $40-60$ & 95 & 79.2 \\
\hline $60-80$ & 7 & 5.8 \\
\hline TOTAL & 120 & 100.0 \\
\hline \multicolumn{3}{|l|}{ Gender } \\
\hline Male & 88 & 73.3 \\
\hline Female & 32 & 26.7 \\
\hline TOTAL & 120 & 100.0 \\
\hline \multicolumn{3}{|l|}{ Marital status } \\
\hline Single & 13 & 10.8 \\
\hline Married & 85 & 70.8 \\
\hline Divorced & 12 & 10.0 \\
\hline Widowed & 10 & 8.3 \\
\hline TOTAL & 120 & 100.0 \\
\hline \multicolumn{3}{|l|}{ Level of education } \\
\hline No formal education & 12 & 10.0 \\
\hline Adult education & 3 & 2.5 \\
\hline Primary level & 39 & 32.5 \\
\hline Secondary level & 44 & 36.7 \\
\hline Tertiary level & 22 & 18.3 \\
\hline Total & 120 & 100.0 \\
\hline \multicolumn{3}{|l|}{ Farming activity } \\
\hline Cattle & 14 & 11.7 \\
\hline Yam & 40 & 33.3 \\
\hline Maize & 4 & 3.3 \\
\hline Cassava & 14 & 11.7 \\
\hline Fish farming & 13 & 10.8 \\
\hline Poultry & 35 & 29.2 \\
\hline TOTAL & 120 & 100.0 \\
\hline \multicolumn{3}{|l|}{ Annual income $(\mathrm{N})$} \\
\hline $20,000-200,000$ & 61 & 50.8 \\
\hline $200,000-400,000$ & 40 & 33.3 \\
\hline $400,000-600,000$ & 13 & 10.8 \\
\hline Above 600,000 & 6 & 5.0 \\
\hline Total & 120 & 100.0 \\
\hline
\end{tabular}

Source, Field survey, 2014

\section{Distribution of Respondents Based on Awareness of ICTs Media}

Table 2 shows the awareness level of farmers of some ICTs media, the study reveals that the respondents were more aware of media such as mobile phones $(99.2 \%)$, television $(98.3 \%)$; radio $(99.2 \%)$ than they are of video-conferencing (30\%), fax (41.7\%), and electronic books (45\%).

Table 2. Distribution of Respondents based on Awareness.

\begin{tabular}{llll}
\hline ICT Media & Yes & No & Total \\
\hline & Frequency (\%) & Frequency (\%) & Frequency (\%) \\
\hline Mobile phone & $119(99.2)$ & $1(0.8)$ & $120(100.0)$ \\
Computer & $102(85.0)$ & $18(15.0)$ & $120(100.0)$ \\
\hline
\end{tabular}

\begin{tabular}{llll}
\hline ICT Media & Yes & N0 & Total \\
\hline & Frequency (\%) & Frequency (\%) & Frequency (\%) \\
\hline Internet & $85(70.8)$ & $35(29.2)$ & $120(100.0)$ \\
E-mail & $71(59.2)$ & $49(40.8)$ & $120(100.0)$ \\
Radio & $119(99.2)$ & $1(0.8)$ & $120(100.0)$ \\
Television & $118(98.3)$ & $2(1.7)$ & $120(100.0)$ \\
Video-conference & $36(30.0)$ & $84(70.0)$ & $120(100.0)$ \\
E-.books & $54(45.0)$ & $66(55.0)$ & $120(100.0)$ \\
Fax & $50(41.7)$ & $70(58.3)$ & $120(100.0)$ \\
\hline
\end{tabular}

Source, Field survey, 2014

Distribution of Respondents based on their Attitudinal Scores.

Table 3 below shows the distribution of respondents based on their attitudinal scores. The attitudinal scores disclosed farmers' perception towards ICTs. Majority of the farmers (72.5\%) had a favourable perception of ICTs, while $27.5 \%$ of the farmers were indifferent in their perception of ICTs, none of the farmers had a non favourable attitude towards ICTs. The result hence, shows that respondents attitude towards ICTs is positive.

Table 3. Attitudinal Scores of Respondents.

\begin{tabular}{lll}
\hline Attitudinal scores & Frequency & Percentage (\%) \\
\hline Below 23 (Non-favorable) & 0 & 0 \\
23- 46 (indifferent) & 33 & 27.5 \\
Above 46 (favorable) & 87 & 72.5 \\
\hline
\end{tabular}

Source, Field survey, 2014

Distribution of Farmers based on source of Information:

Table 4 below revealed the respondents sources of information on farming operations. Family members constitute the major source of information to the famers in the study areas. This is followed by radio, mobile phone and internet while extension agents rarely provide information to the famers.

Table 4. Distribution of Farmers based on source of Information.

\begin{tabular}{llllll}
\hline Source & very freq. & frequent & rarely & not at all & Total \\
\hline $\begin{array}{l}\text { Extension } \\
\text { Agent }\end{array}$ & $0(0)$ & $11(9.2)$ & $88(73.3)$ & $21(17.5)$ & $120(100)$ \\
$\begin{array}{l}\text { Agricultural } \\
\text { shows }\end{array}$ & $1(0.8)$ & $7(5.8)$ & $80(66.7)$ & $32(26.7)$ & $120(100)$ \\
$\begin{array}{l}\text { Internet } \\
\text { Workshops }\end{array}$ & $8(6.7)$ & $54(45.0)$ & $1(0.8)$ & $57(47.5)$ & $120(100)$ \\
$\begin{array}{l}\text { Mobile } \\
\text { phone }\end{array}$ & $11(9.2)$ & $6(5.0)$ & $74(61.7)$ & $40(33.3)$ & $120(100)$ \\
$\begin{array}{l}\text { Family } \\
\text { members }\end{array}$ & $81(67.5)$ & $38(31.7)$ & $1(0.8)$ & $0(0)$ & $120(100)$ \\
$\begin{array}{l}\text { Bulletins } \\
\text { Research }\end{array}$ & $0(0)$ & $21(17.5)$ & $91(75.8)$ & $8(6.7)$ & $120(100)$ \\
$\begin{array}{l}\text { Inst. } \\
\text { Video. }\end{array}$ & $0(0)$ & $2(1.7)$ & $69(57.5)$ & $49(40.8)$ & $120(100)$ \\
Conference & $0(0)$ & $2(1.7)$ & $19(15.8)$ & $99(82.5)$ & $120(100)$ \\
$\begin{array}{l}\text { E-mail } \\
\text { Radio }\end{array}$ & $8(6.7)$ & $38(31.7)$ & $9(7.5)$ & $65(54.2)$ & $120(100)$ \\
$\begin{array}{l}\text { Television } \\
\text { E-book }\end{array}$ & $0(1.7)$ & $70(58.3)$ & $46(38.3)$ & $2(1.7)$ & $120(100)$ \\
\hline
\end{tabular}

Source, Field survey, 2014

Distribution of Respondents based on usage of ICT media. Table 5 shows the distribution of respondents based on 
their usage of ICTs. The table revealed that television, radio and mobile phone top the various forms of ICT usage in the study area.

Table 5. Distribution of Respondents based on their usage of ICTs.

\begin{tabular}{lllll}
\hline Medium & USING & $\begin{array}{l}\text { USED } \\
\text { BEFORE }\end{array}$ & $\begin{array}{l}\text { NEVER } \\
\text { USED }\end{array}$ & TOTAL \\
\hline Mobile Phone & $114(95)$ & $4(3.3)$ & $2(1.7)$ & $120(100)$ \\
Internet & $66(55.0)$ & $3(2.5)$ & $51(42.5)$ & $120(100)$ \\
Computer & $58(48.3)$ & $24(20)$ & $38(31.7)$ & $120(100)$ \\
E-mail & $65(54.2)$ & $1(0.8)$ & $54(45.0)$ & $120(100)$ \\
Radio & $116(96.7)$ & $3(2.5)$ & $1(0.8)$ & $120(100)$ \\
Television & $117(97.5)$ & $1(0.8)$ & $2(1.7)$ & $120(100)$ \\
E-book & $53(44.2)$ & $2(1.7)$ & $65(54.1)$ & $120(100)$ \\
Video. Conference & $8(6.7)$ & $5(4.2)$ & $107(89.1)$ & $120(100)$ \\
Fax & $15(12.5)$ & $11(9.2)$ & $94(78.4)$ & $120(100)$ \\
\hline
\end{tabular}

Source, Field survey, 2014

\section{Hypotheses}

The results of the hypotheses are presented in table 6 .

The hypothesis one states that there is a significant relationship between socio-economic characteristics and use of ICTs. Gender (0.363), Age (0.803), marital status (0.428), farm experience $(0.763)$ and farming activity $(0.797)$ had no significance on the respondent's use of ICTs, while on the other hand educational level $(0.038,16.285)$ had a $5 \%$ level of significance on the use of ICT. This shows that the more educated a respondent is, the more his / her level of ICT usage. It shows that the gender, age, marital status, farming experience and farming activity did not influence the use of ICTs as these factors do not readily come into play when the concept of ICT is discussed, whereas, educational level affects usage of ICT as most ICT commands, instructions can be easily interpreted by a learned person and put to good use.

The hypothesis two shows that there is a significant relationship between attitude towards ICT and usage.

Table 6 also shows the relationship between attitude towards ICT and its usage. It reveals that there is a significant relationship between attitude of respondents towards ICTs and their level of usage. This implies that the attitude of a respondent towards ICT use affects the level at which ICT is made use of. The attitudinal score of respondents had a level of significance. Generally the respondents had a positive attitude towards the use of ICTs, hence, the level of significance observed. This reflects a normal phenomenon where, if one feels positive towards a device one is inclined to use same, and if one does not feel good about a device one could refuse to use same or even out rightly condemned it.

The hypothesis three revealed a significant relationship between attitude towards ICT usage and productivity.

The table shows that there is a significant relationship between attitude of famers towards ICT usage and their subsequent level of productivity. This shows that the attitude of farmers has a significant level of effect on the productivity of farmers. Their attitude had a $10 \%$ level of significance on their productivity. This implies that their attitude towards ICT usage impacted on their level of productivity. From the study, the farmer's positive attitude towards ICT reflected in their level of production. The more receptive a farmer was towards ICTs the more his production.

Table 6. Results of Hypotheses.

\begin{tabular}{lllll}
\hline $\begin{array}{l}\text { 1. Socio-economic } \\
\text { characteristics }\end{array}$ & $\begin{array}{l}\text { Chi-square } \\
\text { value }\end{array}$ & DF & p-value & Decision \\
\hline Gender & 2.028 & 1 & 0.363 & Not Significant \\
Age & 46.851 & 4 & 0.803 & Not Significant \\
Marital status & 5.958 & 3 & 0.428 & Not Significant \\
Educational level & 16.285 & 3 & 0.038 & *Significant \\
Farm experience & 26.009 & 3 & 0.763 & Not Significant \\
Farming activity & 6.211 & 10 & 0.797 & Not Significant \\
2. Attitudinal score & 81.848 & 2 & 0.002 & $* * *$ Significant \\
3. Farm income & 9.328 & 2 & 0.052 & $*$ Significant \\
\hline
\end{tabular}

Note: $*, * *$ and $* * *$ imply level of Significance at $10 \%, 5 \%$ and $1 \%$ respectively.

Source, Field survey, 2014.

\section{Conclusion and Recommendations}

Information, they say is power, which comes through effective communication. Lack of information on the nature and philosophy of the effectiveness of ICT use on agricultural development has a detrimental effect on agricultural productivity. As a result of the findings, it is concluded that a higher percentage of the farmers have considerable income that could enable them to buy different ICTs media to help them source for the needed information that could bring about enhanced productivity. Also, the respondents' attitude towards ICTs was positive while family members constituted the major source of information to the famers. It can be inferred that television, radio and mobile phone top the various forms of ICT usage in the study area. From the results of the study, it can be deduced that ICTs can have far-reaching development impact in providing agricultural role players access to knowledge, information and markets in the globalized world. Many, if not most, activities in the agricultural marketplace are now mediated by web-linked databases specifying prices, qualities and quantities demanded and hence improving productivity. In order to ensure easy and fast access to agricultural information, it is therefore recommended that; policy makers should try to make agricultural information readily available through mobile devices, since they were most commonly used. Also, cost of internet services was the major constraint encountered by farmers, hence, policy makers should work towards reducing the cost of internet access especially to farmers to ensure they have cheap access. Most farmers did not have contact with extension agents; hence more extension agents should be engaged in order to reach the farmers adequately. Since the attitude of respondents affects their level of usage, stakeholders should put measures in place to sensitize the farmers on the advantages of using ICTs and encourage the farmers so that they can use the ICTs. 


\section{References}

[1] United Nations. 2005. The Millennium Development Goals Report 2005. Available at: http://unstats.un.org/unsd/mi/pdf/MDG\%20Book.pdf.

[2] Okumadewa, F. (1997): "Poverty and Income in Nigeria: Measurements and Strategies for Reform”. A paper presented at the Vision 2010 Workshop, Abuja.

[3] Food and Agriculture Organization of the United Nations (2004). Institute building to strengthen agricultural extension. 27th FAO regional conference for Asia and the pacific Beijing, china, May, 17th -21 .

[4] Ortmann, G. F. 2000. Use of information technology in South African agriculture. Agrekon, 39(1): 26-35.

[5] Guermazi, B. and Satola, D. 2005. Creating the "Right" enabling environment for ICT. In Schware, R. (ed). Edevelopment: Excitement to Effectiveness. Washington: World Bank.

[6] Marker et al., 2002. ICT in agriculture: Perspectives of technological innovation. Jerusalem: EFITA.

[7] Jorge, S. 2002. The economics of ICT: challenges and practical strategies of ICT use for women's economic empowerment. Proceedings of the Expert group meeting on "Information communication technologies and their impact on and use as an instrument for the advancement and empowerment of women". Seoul, Korea, 11-14 November 2002.

[8] Fors, E M. \& Moreno, A. 2002. The benefits and obstacles of implementing ICTs strategies for development from a bottomup approach. Aslib Proceedings, 54(3):198-206.

[9] Gelb, E. and Parker, C. 2006. Is ICT Adoption for Agriculture Still an Important Issue? Proceedings, $5^{\text {th }}$ AFITA Conference, Bangloru, India.

[10] Miranda, F. R., Yoder, R. E., Wilkerson, J. B. \& Odhiambo, L.O. 2005. An autonomous controller for Site-specific management of fixed irrigation Systems. Computers and Electronics in Agriculture, 48:183-197. 